\title{
Childhood predictors and age 48 outcomes of self-reports and official records of offending
}

\author{
ERIC F. DUBOW ${ }^{1,2}$, L. ROWELL HUESMANN ${ }^{1}$, PAUL BOXER ${ }^{1,3}$ AND \\ CATHY SMITH ${ }^{1},{ }^{1}$ The University of Michigan, MI USA; ${ }^{2}$ Bowling Green \\ State University, OH USA; ${ }^{3}$ Rutgers University, NJ USA
}

\section{ABSTRACT}

Background The key question is: are self-reports and official records equally valid indicators of criminal offending?

Aims We examine the correspondence between self-reports and official records of offending, the similarity of childhood and adolescent individual and contextual predictors of both measures of offending, and the similarity of age 48 correlates of both measures of offending.

Methods Men $(\mathrm{N}=436)$ from the Columbia County Longitudinal Study, a sample of all 3rd graders in Columbia County, New York, in 1959-60, participated. The youth, their peers and their parents were interviewed when the youth were age 8; the youth were later interviewed at ages 19,30 and 48.

Results We found moderate to high correspondence between self-reports of having been in trouble with the law and official arrest records. Lifetime self-reports and official records of offending were generally predicted by the same childhood and adolescent variables, and were correlated with many of the same adult outcome measures. By age 48, life-course non-offenders defined by either self-reports or official records had better outcomes than offenders.

Conclusions The results validate the use of adolescent and adult self-reports of offending, and the early identification of individuals at risk for adult criminal behaviour through childhood parent and peer reports and adolescent self and peer reports. Copyright (C) 2014 John Wiley $\mathcal{E}$ Sons, Ltd.

\section{Introduction}

We use data from a prospective study of a community sample of men followed from age 8 to age 48. First, we examine the correspondence between self-reports and official records of offending during adolescence, early adulthood and middle 
adulthood. Second, we examine childhood and adolescent predictors of selfreports and official records across the life-course. Predictors included child, individual and family variables posited by developmental-contextual models of the development of antisocial behaviour (e.g. Patterson, 1982; Gottfredson and Hirschi, 1990; Catalano and Hawkins, 1996; Huesmann, 1998; Thornberry, 2005). Third, we examine adult correlates of offending. Research has shown poorer mental and physical health, social and economic adult outcomes for offenders compared with non-offenders (e.g. Piquero et al., 2007; Bergman and Andershed, 2009; Farrington et al., 2009; Pulkkinen et al., 2009).

The strengths of studying these issues in the Columbia County Longitudinal Study are as follows: the research design is prospective, with interviews at four developmental periods (childhood, late adolescence, early adulthood and middle adulthood); data were collected using multiple methods (e.g. parent reports, peer nominations, self-reports and official criminal records); and the participants were the entire population of third-graders in a socioeconomically heterogeneous county in the USA.

\section{Method}

\section{Participants and procedures}

The data come from the Columbia County Longitudinal Study, initiated by Eron et al. (1971) as a longitudinal study of 436 boys who were in the third grade in 1960 (modal age $=8$ ) in Columbia County, New York, a semi-rural area. All 38 public and private third-grade classrooms in the county participated. Over $90 \%$ of the sample was Caucasian. In this first wave, $85 \%$ of the participants' mothers and $71 \%$ of their fathers were also interviewed. The participants came from a broad range of socioeconomic backgrounds (based on Warner et al. (1960) scale), and displayed a wide range of intelligence. In 1970-1972, 211 men were re-interviewed. They had a modal age of 19 years and had completed 12.6 years of education on average. In 1981-1982, 198 of the men were reinterviewed (modal age 30). During 1999-2002, 268 men (61\% of the original sample) were re-interviewed; their mean age was 48.46 years old; their average education level was between some college and a college degree; their average occupational attainment was middle-class status (based on Stevens and Hoisington's (1987) occupational prestige scores); and $69 \%$ of the original participants were living with their spouses.

Data collection procedures have been reported elsewhere (e.g. Eron et al., 1971; Lefkowitz et al., 1977; Huesmann et al., 1984; Huesmann et al., 2002; Dubow et al., 2009; Huesmann et al., 2009). Age 8 data were derived from classroom-based peer nominations and individual parent interviews. At age 19, participants were administered self-report measures, and peer nominations were again obtained in individual interviews at a field office. At ages 30 and 48, 
interviews were conducted by computer in a field office and by mail/telephone for participants who could not come to the office.

\section{Attrition information}

At age 48 , we interviewed $61 \%(n=268)$ of the original sample of men. A comparison of means on age 8 scores revealed no significant difference in father's occupational status; however, compared with participants who were re-interviewed at age 48, participants who were not re-interviewed had higher levels of aggression, lower levels of popularity and lower IQ at age 8 . These effect sizes ranged from $r=.14$ to $r=.19$. However, the plots of the distributions for these age 8 variables revealed that many of the high aggressive and low competent participants were re-sampled and there was no substantial restriction of range.

\section{Measures}

Self-report of trouble with the law/arrests

At modal ages 19 (1971), 30 (1982) and 48 (2000), participants were asked to respond to the Minnesota Multiphasic Personality Inventory (Hathaway and McKinley, 1940) item, 'I have never been in trouble with the law' (False, True); and at age 48, they were also asked if they had ever been arrested in their lifetime and ever arrested in the past 5 years for anything other than a minor traffic offence (Elliott et al., 1985). In 1971 (modal age 19), 32\% of men reported that 'yes, they had been in trouble with the law;' in 1982 (modal age 30), 36\% said 'yes'; and in 2000 (modal age 48), 42\% said 'yes.' At age 48, 5\% also reported they had been arrested sometime in their life and $4 \%$ reported they had been arrested in the past 5 years.

\section{Official criminal arrest records}

During the 1982 and 2000 data collections, criminal history data were obtained from the New York State Criminal Justice Archive and driver licence records from the NY State Department of Motor Vehicles. For this paper, we use only the criminal records obtained in 2000 as they are cumulative. The criminal

\footnotetext{
${ }^{1}$ There is an important limitation to the self-report item: 'I have never been in trouble with the law.' If a participant responded 'yes' at age 19 and also responded 'yes' in adulthood (age 30 or 48), the 'yes' in adulthood could refer back to being in trouble with the law before age 19 , and not subsequently. However, we conducted analyses that lend to confidence that participants' responses to the item in adulthood reflect more recent behaviour. First, we found that of the total sample (men and women) of participants who reported having been in trouble with the law at age 19, 55\% reported that they were never in trouble with the law at age 30 and $61 \%$ reported that they had never been in trouble with the law at age 48. Also, we computed regressions predicting official reports of arrest at age 30 and at age 48 from the current self-report item ('I have never been in trouble with the law') as well as the same item the participant responded to in previous waves. In both regressions, the self-report item at the same time point significantly predicted arrests at that time point, even after controlling for the self-report item at previous time points.
} 
records include all arrests reported to the state agency because the participants were age 18 . We coded for arrests corresponding to three time points related to the interview dates: 1970-1972 (modal ages 18-20, late adolescence); 1973-1982 (modal ages 21-30, early adulthood); and 1983-2000 (modal ages 31-48, middle adulthood). The New York State Criminal Justice Archive only contains records for persons who had been arrested in New York State; we do not have data on arrests that may have occurred in other states. We assessed whether each of the participants was a New York State resident during each of the crime reporting periods. We counted them as a resident (a) if they had a criminal record during the period (b) if they had a New York drivers licence during the period or a subsequent period or (c) if we found that they had a home address in New York State during the period. We found that 368 men were residents during adolescence and 34 of them (9.2\%) were 'official offenders' during that period; 319 were residents during early adulthood and 82 of them $(25.7 \%)$ were official offenders; and 308 were residents during middle adulthood and 48 of them $(15.6 \%)$ were official offenders. ${ }^{2}$

\section{Lifetime official offenders or non-offenders}

There were 436 men who were residents of New York State during at least some of the time on which we collected official arrest data, and 109 (25\%) of them were classified as Life-time Official Offenders because there was a record of their being arrested at least once from age 18 on. To be classified as a Life-time Official Non-offender, however, a man had to be a resident in all data collection periods (1970, 1980 and 2000) and not had a single arrest in any of them. Of the 436 men, 308 were residents in all periods, and $213(69.2 \%)$ of them $(48.9 \%$ of the 436) were classified as Official Non-offenders. The other 114 men $(26.1 \%$ of the 436) could not be classified.

\section{Lifetime self-report offenders versus non-offenders}

Men were classified as Life-time Self-report Offenders if they self-reported 'being in trouble with the law' at least once when they were interviewed (ages 19, 30 or 48) or if they reported that they had ever been arrested in their life at age 48. There were 336 men who were interviewed at least once, and 162 (48.2\%) of them were classified as Life-time Self-report Offenders. In contrast, to be classified as a Life-time Self-report Non-offender, a man had to be interviewed at least twice

\footnotetext{
${ }^{2}$ We included driving while intoxicated offences because the self-report items do not discriminate types of offences in terms of 'being in trouble with the law.' Indeed, concordance between official records and self-report of being in trouble with the law decreased when driving while intoxicated offences were not included: concordance decreased during adolescence $0.3 \%$, during early adulthood $2.2 \%$ and during middle adulthood $4.3 \%$. The pattern of results for childhood and adolescent predictors of offending, and relations between offending and age 48 outcomes, remained largely the same with or without driving while intoxicated offences. Results that do not include driving while intoxicated offences can be obtained by contacting the first author.
} 
- once in adolescence and once in adulthood - and had to self-report never being in trouble with the law in both interviews. There were 181 men who were interviewed in adolescence and at least one time in adulthood (1980 or 2000): 72 (39.8\%) of them (and $21.4 \%$ of the 336) were classified as Life-time Self-report Non-offenders. The remaining 102 (30.4\% of the 336) could not be classified.

\section{Predictor variables}

A detailed description of all predictor variables, along with references describing their psychometric characteristics, can be obtained by contacting the first author.

Child, parent and family predictors from 1960 age 8 data

From birth certificates, we coded the child's birth weight and the age of the mother at child's birth. From parents, we assessed family background variables including the number of children in the family, parents' education, value of family housing and parents' church attendance (Eron et al., 1971). We also measured parents' delinquency and authoritarianism (Adorno et al., 1950), and family interaction variables including parental rejection of the child, parents' endorsement of punishment for child, parental disharmony and the child's identification with the parent (Eron et al., 1971; Eron et al., 1991). We assessed the child's IQ (Sullivan et al., 1957), peer-nominated aggression and popularity, and the child's expression of guilt and confession about transgressions (Eron et al., 1971; Huesmann and Eron, 1986).

\section{Adolescent predictors from 1971 age 19 data}

We assessed self-reports of educational attainment; educational, occupational and income aspirations; church attendance; identification with the parent; antisocial behaviour (Elliott and Voss, 1974) and aggression; the extent to which the participant witnessed and was victimised by aggression; and depression (Hathaway and McKinley, 1940). We also assessed peer-nominated aggression and popularity.

Adult outcome variables from age 48 data

We assessed educational attainment, verbal achievement (Jastak and Jastak, 1978), occupational status, church attendance, antisocial behaviours, aggression, aggression towards spouse (Straus et al., 1980) (self and spouse reports combined), traffic violations, depression (Derogatis, 1992), problem drinking (Dubow et al., 2008), drug use and ever divorced. 
Table 1: Correspondence between men's self-reports of having 'ever been in trouble with the law' and official records of arrest during adolescence, early adulthood or middle adulthood for men who were interviewed in the same period and were New York State residents

\begin{tabular}{|c|c|c|c|}
\hline \multirow{2}{*}{$\begin{array}{l}\text { Official records } \\
\text { of arrest }\end{array}$} & \multicolumn{3}{|c|}{$\begin{array}{l}\text { Number }(\%) \text { who self-reported in the concurrent } \\
\text { interview that they had 'ever' been in trouble with the } \\
\text { law }\end{array}$} \\
\hline & Never in trouble & Ever in trouble & \\
\hline \multicolumn{4}{|c|}{ Adolescence: arrests age 18-20 for resident men interviewed at age 19} \\
\hline No arrests age $18-20$ & $139(69.5)$ & $61(30.5)$ & $200(94.8)$ \\
\hline \multirow[t]{2}{*}{ Arrested at least once } & $5(45.5)$ & $6(54.5)$ & $11(5.2)$ \\
\hline & $144(68.2)$ & $67(31.8)$ & 211 \\
\hline \multicolumn{4}{|l|}{$\chi^{2}(1)=2.78 \dagger$} \\
\hline \multicolumn{4}{|c|}{ Early adulthood: arrests age $21-32$ for resident men interviewed at age 30} \\
\hline No arrests age $21-32$ & $78(80.4)$ & $19(19.6)$ & $97(74.6)$ \\
\hline \multirow[t]{2}{*}{ Arrested at least once } & $5(15.2)$ & $28(84.8)$ & $33(25.4)$ \\
\hline & $83(63.8)$ & $47(36.2)$ & 130 \\
\hline \multicolumn{4}{|c|}{$\chi^{2}(1)=45.43 * * *$} \\
\hline \multicolumn{4}{|c|}{ Middle adulthood: arrests age 33-48 for resident men interviewed at age 48} \\
\hline No arrests age $33-48$ & $105(65.2)$ & $56(34.8)$ & $161(85.2)$ \\
\hline \multirow[t]{2}{*}{ Arrested at least once } & $1(3.6)$ & $27(96.4)$ & $28(14.8)$ \\
\hline & $106(56.1)$ & $83(43.9)$ & 189 \\
\hline \multicolumn{4}{|l|}{$\chi^{2}(1)=36.80 * * *$} \\
\hline \multicolumn{4}{|c|}{ Lifetime: arrests in lifetime for anytime resident men interviewed at age 48} \\
\hline No arrests in lifetime & $100(73.5)$ & $36(26.5)$ & $136(72.0)$ \\
\hline \multirow[t]{2}{*}{ Arrested at least once } & $6(11.3)$ & $47(88.7)$ & $53(28.0)$ \\
\hline & $106(56.1)$ & $83(43.9)$ & 189 \\
\hline \multicolumn{4}{|l|}{$\chi^{2}(1)=59.92 * * *$} \\
\hline
\end{tabular}

Note: ${ }^{a}$ This contingency coefficient under-estimates the true relation by the extent to which participants included contacts with the law prior to the official record period in their concurrent self-reports of 'ever' being in trouble with the law.

${ }^{+} p<.10, * p<.05, * * p<.01, * * * p<.001$.

\section{Results}

Correspondence between self-reports and official records of offending from adolescence through middle adulthood

Table 1 includes data for men who were interviewed at each time point and were New York State residents at that time and shows the correspondence between self-reports and official records. 
By the end of 1972 (modal age 20), 11 men had an arrest record and 200 did not; 67 men had self-reported 'being in trouble with the law' and 144 denied it. Thus, men were 2.5 times more likely to report being in trouble if they were arrested versus not arrested, and they were 2.74 times more likely to report not being in trouble if they were not arrested than if they were arrested.

During early adulthood, between 1973 and 1982 (modal ages 21-30), 33 men had an arrest and 97 men did not, compared with self-reports of 47 being in trouble with the law and 83 never being in trouble. Thus, men were 22.95 times more likely to report being in trouble if they were arrested versus not arrested, and they were 22.83 times more likely to report not being in trouble if they were not arrested than if they were arrested.

In middle adulthood, between 1983 and 2000 (modal ages 31-48), 28 men had an arrest and 161 men did not, compared with self-reports of 83 being in trouble with the law and 106 never being in trouble. Thus, men were 50.94 times more likely to report being in trouble if they were arrested versus not arrested, and they were 47 times more likely to report not being in trouble if they were not arrested than if they were arrested.

As described earlier, we categorised 109 men as Life-time Official Offenders meaning they had at least one documented arrest, and 213 men as Life-time Official Non-offenders meaning they were residents continuously and they never had a documented arrest. In the bottom panel of Table 1, we examine the subset of these men $(N=189)$ who were interviewed at age 48 . We cross compare their lifetime offender status according to the official records with their self-reports in the year 2000 (modal age 48) of 'ever' being in trouble with the law: 53 of these men were arrested at least once and 136 were never arrested, compared with self-reports of 83 being in trouble with the law at some time and 106 never being in trouble with the law. Thus, men were 21.76 times more likely to report being in trouble if they were arrested versus not arrested, and they were 21.38 times more likely to report not being in trouble if they were not arrested than if they were arrested.

\section{Childhood and adolescent predictors of offending}

Childhood predictors

Table 2 shows that nine of the childhood variables discriminated the lifetime non-offenders from offenders, and the findings were moderately consistent between self-reports and official records. According to both self-reports and official reports, parents of offenders had significantly lower levels of education and more children in the family, and at age 8 , the offenders were significantly more aggressive and less intelligent. Next, we computed step-wise logistic regressions ( $p<.10$ required for entry) to examine the independent effects of the predictors. The two models (one predicting self-reports of ever offending 


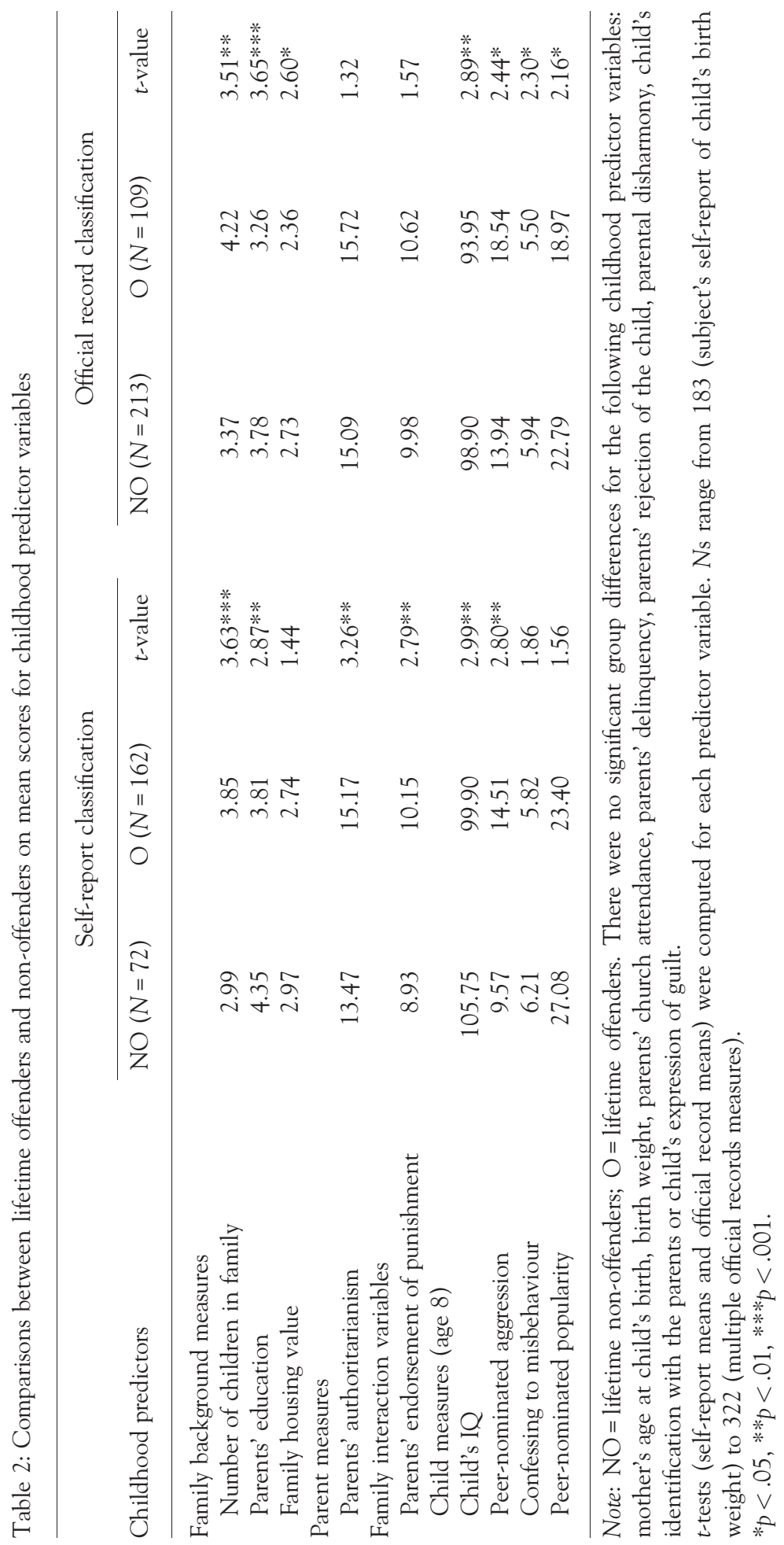


and one predicting official reports of ever offending) had excellent fits $\left(\chi^{2} / d f s\right.$ ranged from 7.45 to 9.34 , ps $<.001$ ). Being a self-reported offender was predicted by having more children in the family during childhood (AOR (adjusted odds ratio $)=1.75, p<.05)$, more authoritarian parents $(\mathrm{AOR}=2.14, p<.05)$ and higher peer-nominated aggression at age $8(\mathrm{AOR}=1.46, p=.10)$. Having an official arrest record by age 48 was also predicted by higher peer-nominated aggression at age $8(\mathrm{AOR}=1.39, p<.05)$ and having less educated parents $(\mathrm{AOR}=2.03, p<.001)$.

\section{Adolescent predictors}

Table 3 shows that seven of the adolescent variables discriminated the lifetime non-offenders from the offenders, and the findings were highly consistent between self-reports and official records. According to both self-reports and official reports of offending, men who offended at some time during their lives had lower educational aspirations; higher self-reported antisocial behaviour and aggression; higher peer-nominated aggression; and higher levels of witnessing and being victimised by aggression.

Again, we computed two logistic regressions: both models had an excellent fit $\left(\chi^{2} / d f\right.$ s ranged from 7.23 to 9.21 , ps $\left.<.001\right)$. Being a self-reported offender was predicted by higher peer-nominated aggression $(\mathrm{AOR}=2.73, \quad p<.01)$, witnessing more violence $(\mathrm{AOR}=1.87, \mathrm{p}<.01)$, and having lower levels of depression $(\mathrm{AOR}=.70, p<.10)$. Only one adolescent variable independently predicted official arrest records: a one standard deviation increase in antisocial behaviour more than doubled the chances of having an arrest record $(\mathrm{AOR}=2.20$, $p<.01)$.

\section{Adult correlates of offending}

Table 4 shows that 11 of the adult outcome variables discriminated the lifetime non-offenders from the offenders, and again the findings were highly consistent between self-reports and official records. According to both self-reports and official reports, offenders had lower educational attainment than non-offenders, lower verbal achievement, lower occupational status, higher self-reported aggression and aggression towards spouse, more minor traffic violations, more problems with drinking and more drug use.

\section{Discussion}

Like other studies, we found a moderate to high degree of correspondence between self-reports of offending and official arrest records. Although different biases affect self-reports and official records, both methods appear to be useful and valid (e.g. Huizinga and Elliott, 1986; Farrington et al., 2003; Thornberry 


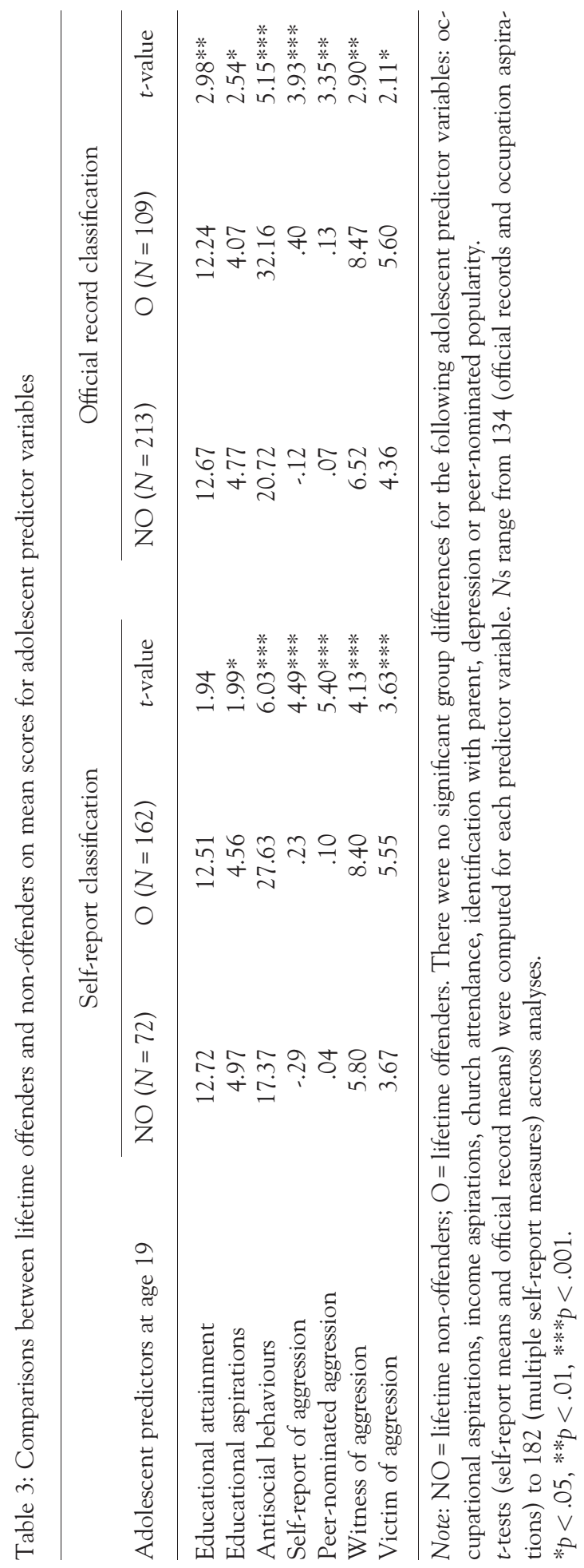




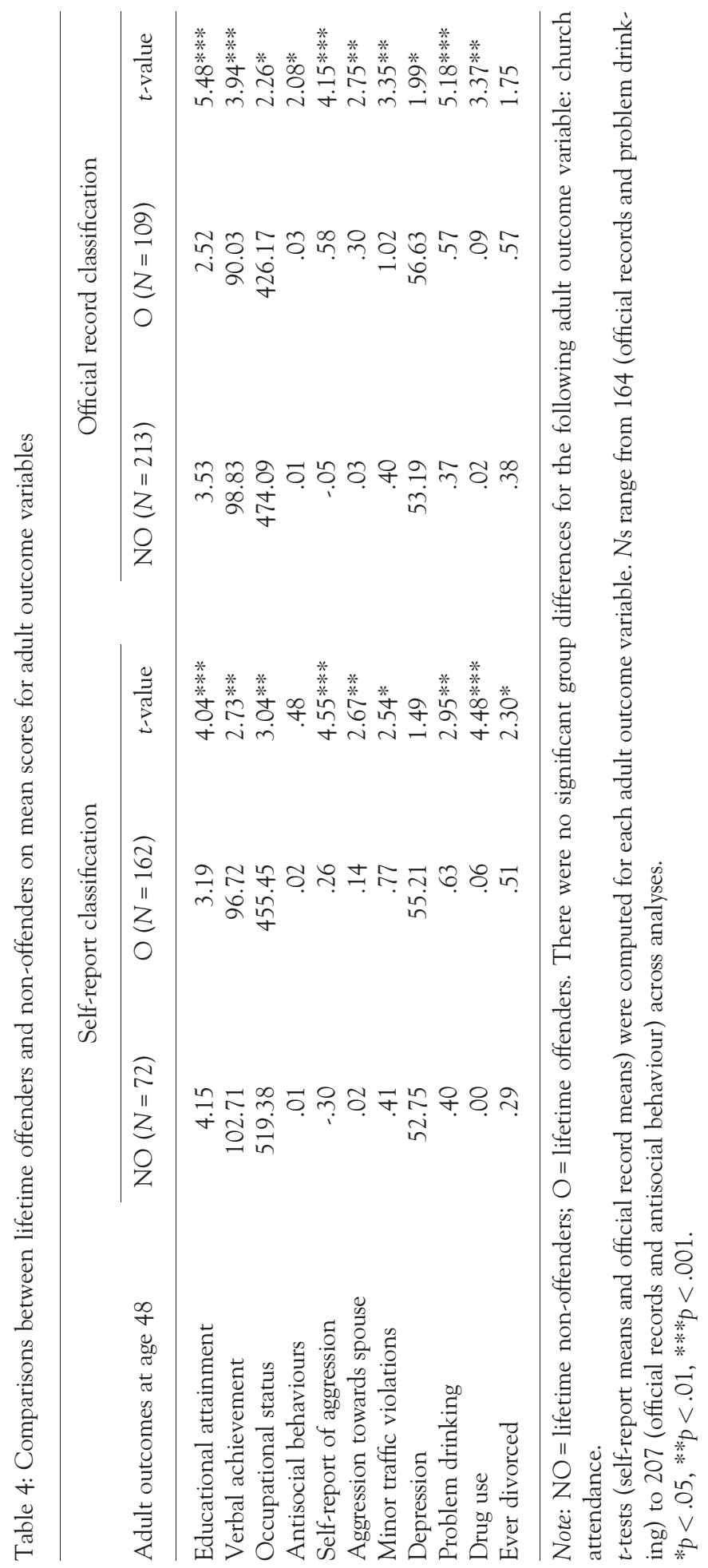


and Krohn, 2003; Jolliffe and Farrington, 2014). Having an official arrest being corroborated by self-reported trouble with the law increased with age from adolescence $(69 \%)$ to early adulthood $(82 \%)$ and back down in middle adulthood (70\%). Lifetime official offending corresponded very well with middle adulthood self-reports $(78 \%)$.

Self-reports and official reports of offending by age 48 generally were predicted by the same childhood and adolescent variables, and also were consistently correlated with the same adult variables. These results are consistent with those of other studies (e.g. Farrington, 1986, 1994; Chung et al., 2002; Sampson and Laub, 2003; Thornberry, 2005; Piquero, 2008; Bergman and Andershed, 2009), further suggesting that self-reports are a valid and useful complement to official records.

Our findings are especially noteworthy because the participants were not a high-risk sample but rather a middle-class, predominantly Caucasian community sample. The current sample (25\% with an arrest record by age 48 ) appears to have a somewhat lower arrest rate than that of a more recent national sample of Caucasian early adults (38\%; Brame et al., 2014). Still our findings predicting offending through age 48 are consistent with others' findings, and extend our previous research predicting official records of offending through age 30. In Huesmann et al. (2002) and here, we found that several childhood variables were related to adult criminality by themselves, but not uniquely (e.g. low IQ, poor housing and child not confessing transgressions); yet, childhood aggression still showed an independent effect. It is possible that these other factors exert their effects earlier than age 8 on the child's aggression, and aggression then mediates their effects. Of course, it also is possible that childhood aggression predicts adult offending because both are reflective of the same underlying process (e.g. temperamental or genetic vulnerabilities). These findings provide further support for the need for prevention programmes to target family and early childhood factors before antisocial behaviour becomes a pattern that can lead to socioeconomic, social and behavioural problems by middle adulthood.

\section{Acknowledgements}

The authors wish to acknowledge the pioneering contributions of Leonard Eron, Monroe Lefkowitz and Leopold Walder to the Columbia County Longitudinal Study.

This research has been supported by funding from the Columbia County Tuberculosis and Health Association and the Hudson (NY) Lions Club (1960 wave); the National Institute of Mental Health (1960, 1970 and 1981 waves); and the National Institute of Child Health and Human Development (2000 wave; Grant number HD36506). 


\section{References}

Adorno TW, Frenkel-Brunswick E, Levinson DJ, Sanford NR (1950) The Authoritarian Personality. New York: Harper.

Bergman LR, Andershed A (2009) Predictors and outcomes of persistent or age-limited registered criminal behavior: A 30-year longitudinal study of a Swedish urban population. Aggressive Behavior 35: 164-178. doi: 10.1002/ab.20298.

Brame R, Bushway SD, Paternoster R, Turner MG (2014) Demographic patterns of cumulative arrest prevalence by ages 18 and 23. Crime $\mathcal{E}$ Delinquency (early online version). doi: 10.1177/ 0011128713514801.

Catalano RF, Hawkins JD (1996) The Social Development Model: A theory of antisocial behavior. In Hawkins JD (ed.) Delinquency and Crime: Current Theories. Cambridge: Cambridge University Press pp. 149-197.

Chung I-J, Hill KG, Hawkins D, Gilchrist LD, Nagin DS (2002) Childhood predictors of offense trajectories. Journal of Research in Crime and Delinquency 39: 60-90. doi: 10.1177/ 002242780203900103.

Derogatis LR (1992) BSI: Administration, Scoring, and Procedures Manual - II. Towson, MD: Clinical Psychometric Research.

Dubow EF, Boxer P, Huesmann LR (2008) Childhood and adolescent predictors of early and middle adulthood alcohol use and problem drinking: The Columbia County Longitudinal Study. Addiction 103: 36-47. doi: 10.1111/j.1360-0443.2008.02175.x.

Dubow EF, Boxer P, Huesmann LR (2009) Long-term effects of parents' education on children's educational and occupational success: Mediation by family interactions, child aggression, and teenage aspirations. Merrill-Palmer Quarterly 55: 224-249. PMC2853053. doi: 10.1353/mpq. 0.0030 .

Elliott DS, Voss HL (1974) Delinquency and Dropout. Lexington, MA: Lexington Books.

Elliott DS, Huizinga D, Ageton SS (1985) Explaining Delinquency and Drug Use. Beverly Hills, CA: Sage Publications.

Eron LD, Walder LO, Lefkowitz MM (1971) The Learning of Aggression in Children. Boston: Little Brown.

Eron LD, Huesmann LR, Zelli A (1991) The role of parental variables in the learning of aggression. In Pepler D, Rubin K (eds) The Development and Treatment of Childhood Aggression. Hillsdale, NJ: Lawrence Erlbaum Associates pp. 169-188. doi: 10.4324/ 9780203771693.

Farrington DP (1986) Age and crime. In Tonry M, Morris N (eds) Crime and Justice, Vol. 7. Chicago: University of Chicago Press pp. 189-250.

Farrington D (1994) Early developmental prevention of juvenile delinquency. Criminal Behaviour EO Mental Health 4: 209-227.

Farrington DP, Jolliffe D, Hawkins JD, Catalano RF, Hill KG, Kosterman R (2003) Comparing delinquency careers in court records and self-reports. Criminology 41: 933-958. doi: 10.1111/ j.1745-9125.2003.tb01009.x.

Farrington DP, Ttofi MM, Coid JW (2009)Development of adolescence-limited, late-onset, and persistent offenders from age 8 to age 48. Aggressive Behavior 35: 150-163. doi: 10.1002/ ab.20296.

Gottfredson MR, Hirschi T (1990) A General Theory of Crime. Stanford, CA: Stanford University Press.

Hathaway SR, McKinley JC (1940) The MMPI Manual. New York: Psychological Corporation.

Huesmann LR (1998) The role of social information processing and cognitive schema in the acquisition and maintenance of habitual aggressive behavior. In Geen RG, Donnerstein E (eds) Human Aggression: Theories, Research, and Implications for Social Policy. San Diego, CA: Academic Press pp. 73-109. 
Huesmann LR, Eron LD (eds) (1986) Television and the Aggressive Child: A Cross-National Comparison. Hillsdale, NJ: Lawrence Erlbaum Associates. doi: 10.4324/9780203380130.

Huesmann LR, Eron LD, Lefkowitz MM, Walder LO (1984) The stability of aggression over time and generations. Developmental Psychology 20: 1120-1134. doi: 10.1037/0012-1649.20.6.1120.

Huesmann LR, Eron LD, Dubow EF (2002) Childhood predictors of adult criminality: Are all risk factors reflected in childhood aggressiveness? Criminal Behaviour and Mental Health 12: 185-208. doi: $10.1002 / \mathrm{cbm} .496$.

Huesmann LR, Dubow EF, Boxer P (2009) Continuity of childhood, adolescent, and early adulthood aggression as predictors of adult criminality and life outcomes: Implications for the adolescent-limited and life-course-persistent models. Aggressive Behavior 35: 136-149. doi: 10.1002/ab.20300.

Huizinga D, Elliott DS (1986) Reassessing the reliability and validity of self-report measures. Journal of Quantitative Criminology 2: 293-327. doi: 10.1007/BF01064258.

Jastak JF, Jastak S (1978) The Wide Range Achievement Test Manual of Instructions (1978 revised ed.). Wilmington, DE: Jastak Associates, Inc.

Jolliffe D, Farrington DP (2014) Self-reported offending: Reliability and validity. In Bruinsma GJN, Weisburd DL (eds) Encyclopedia of Criminology and Criminal Justice. New York: Springer. doi: 10.1007/978-1-4614-5690-2_648.

Lefkowitz MM, Eron LD, Walder LO, Huesmann LR (1977) Growing Up to Be Violent: A Longitudinal Study of the Development of Aggression. New York: Pergamon.

Patterson GR (1982) A Social Learning Approach. Coercive Family Processes, Vol. 3. Eugene, OR: Castalia. doi: 10.1016/S0005-7894(84)80046-5.

Piquero AR (2008) Taking stock of developmental trajectories of criminal activity over the life course. In Liberman AM (ed.) The Long View of Crime: A Synthesis of Longitudinal Research. New York: Springer pp. 23-78. doi: 10.1007/978-0-387-71165-2_2.

Piquero AR, Daigle LE, Gibson C, Piquero NL, Tibbets SG (2007) Are life-course-persistent offenders at risk for adverse health outcomes? Journal of Research in Crime and Delinquency 44: 185-207. doi: 10.1177/0022427806297739.

Pulkkinen L, Lyyra A, Kokko K (2009) Life success of males on nonoffender, adolescence-limited, persistent, and adult-onset antisocial pathways: Follow-up from age 8 to 42. Aggressive Behavior 35: 117-135. doi: 10.1002/ab.20297.

Sampson RJ, Laub JH (2003) Life-course desisters? Trajectories of crime among delinquent boys followed to age 70. Criminology 41: 555-592. doi: 10.1111/j.1745-9125.2003.tb00997.x.

Stevens G, Hoisington E (1987) Occupational prestige and the 1980 U.S. labor force. Social Science Research 6: 74-105. doi: 10.1016/0049-089X(87)90019-6.

Straus MA, Gelles RJ, Steinmetz SK (1980) Behind Closed Doors: Violence in American Families. New York: Doubleday. doi: 10.1016/0145-2134(83)90043-1.

Sullivan ET, Clark WW, Tiegs EW (1957) California Short Form Test of Mental Maturity. Los Angeles: California Test Bureau. doi: 10.1016/0022-4405(68)90056-3.

Thornberry TP (2005) Explaining multiple patterns of offending across the life course and across generations. The Annals of the American Academy of Political and Social Science 602: 156-195. doi: $10.1177 / 0002716205280641$.

Thornberry TP, Krohn MD (2003) Comparison of self-report and official data for measuring crime. In Pepper JV, Petrie CV (eds) Measurement Problems in Criminal Justice Research: Workshop Summary. Washington, DC: National Academy Press pp. 43-94.

Warner WL, Meeker M, Eells K (1960) Social Class in America. New York: Harcourt.

Address correspondence to: Eric F. Dubow, Department of Psychology, Bowling Green State University, Bowling Green, OH 43403, USA. Email: edubow@ bgsu.edu 